\title{
Ertelenen Cerrahi Girişimlerin Nedenleri ve Hasta Anksiyete Düzeyine Etkisi
}

\section{The Reasons for Cancellation of Elective Surgical Interventions and Its Effect on Patient Anxiety Level}

\author{
Elif Karahan ${ }^{1 *}$, Sevim Çelik ${ }^{2}$, Funda Zaman ${ }^{3}$ \\ ${ }^{1}$ Zonguldak Bülent Ecevit Üniversitesi Sağlık Bilimleri Fakültesi, Hemşirelik Bölümü, Cerrahi Hastalıkları \\ Hemşireliği Anabilim Dalı, Zonguldak, Türkiye \\ ${ }^{2}$ Bartın Üniversitesi Sağlık Bilimleri Fakültesi, Hemşirelik Bölümü, Cerrahi Hastalıkları Hemşireliği Anabilim \\ Dal, Bartın, Türkiye \\ ${ }^{3}$ Zonguldak Bülent Ecevit Üniversitesi Sağlık Uygulama ve Araştırma Merkezi, Zonguldak, Türkiye
}

e-mail: elifim67@yahoo.com, sevimakcel@yahoo.com, funda.z@hotmail.com

ORCID:0000-0002-6371-871X

ORCID:0000-0002-2016-5828

ORCID: 0000-0002-9245-5184

*Sorumlu Yazar/Corresponding Author: Elif KARAHAN

Gönderim Tarihi / Received:02.08.2019

Kabul Tarihi / Accepted:31.03.2020

DOI: $0.34087 /$ cbusbed.600917

Giriș ve Amaç: $\mathrm{Bu}$ araştırmanın amacı hastaneye yatıs yapılarak cerrahi girișim uygulanması planlanan ancak ameliyatı ertelenen hastalarda ertelenme nedenlerinin incelenmesi ve bu durumun hastaların anksiyete düzeyi üzerine olan etkisini belirlemektir.

Gereç ve Yöntemler: Araştırma Batı Karadeniz Bölgesinde yer alan bir Sağlık Uygulama ve Araştırma Merkezi’nin genel cerrahi servisi, ortopedi ve travmatoloji servisinde yatan gönüllü 100 hasta ile gerçekleştirildi. Hastalar; cerrahi girişimi ertelenen $(n=50)$ ve ertelenmeyen $(n=50)$ şeklinde iki gruba ayrıldı. Verilerin toplanmasında; Hasta Bilgi Formu, Durumluk Anksiyete ve Sürekli Anksiyete Ölçeği Ölçeği kullanıldı. Tanımlayıcı analizlerle birlikte, Student $\mathrm{t}$ testi, Pearson Kikare testi ve Fisher-Freeman-Halton Exact Testi ile istatistiksel analiz yapıldı.

Bulgular: Bu araştırmada 61-80 yaş aralığında olan hastalarda ertelenme oranının anlamlı düzeyde yüksek olduğu saptandı. Cerrahi girişimin ertelenme nedenleri sıklıkla enfeksiyon/ ateş ve akciğer fonksiyonlarında ani değişikliklerdi. Ameliyatın ertelendiğini açıklayan kişinin $\% 50$ oranında asistan, $\% 40$ oranında ise hemşireler olduğu ve hastaların \%60'ının ameliyatın ertelenme açıklamasından tatmin olduğu belirlendi. İki grup karşılaştırıldığında hastaların durumluk kaygı puanları arasında istatistiksel olarak anlamlı farklılık olmadığı ancak cerrahi girişimi ertelenen hastaların sürekli kaygı puan ortalamalarının diğer gruba göre daha yüksek olduğu tespit edildi.

Sonuç: Planlanan cerrahi girişimin ertelenmesinin hastaların sürekli kaygı düzeyini arttırdığı sonucuna varıldı.

Anahtar Sözcükler: Ameliyat, anksiyete, Durumluk-Süreklilik Kayg 1 Ölçeği, ertelenen cerrahi

\begin{abstract}
Objective: The aim of this study was to investigate the reasons for cancellation of the patients who were planned to be hospitalized and who were scheduled to undergo surgery but to cancellation the operation and to determine the effect of this situation on the anxiety level of the patients.

Materials and Methods: The study was carried out with 100 volunteer patients hospitalized in the general surgery service, orthopedics and traumatology service of a Health Application and Research Center in the Western Black Sea Region. Patients; Surgical intervention was divided into two groups as postponed $(n=50)$ and non-postponed $(n=50)$. In the collection of data; Patient Information Form, State Anxiety and Continuous Anxiety Scale Scale were used. Statistical analysis was performed with Student $t$ test, Pearson Chi-square test and Fisher-Freeman-Halton Exact Test with descriptive analyzes.

Results: In this study, the rate of cancellation was found to be significantly higher in patients aged 61-80 years. The reasons for cancellation of the surgical procedure were infection / fever and sudden changes in lung function. It was
\end{abstract}


determined that $50 \%$ of the patients were assistants, $40 \%$ were nurses and $60 \%$ of the patients were satisfied with the cancellation of the operation. When the two groups were compared, it was found that there was no statistically significant difference between the state anxiety scores of the patients, but the mean anxiety scores of the patients whose postoperative surgery was postponed were higher than the other groups.

Conclusion: It was concluded that delaying the planned surgical intervention increased the anxiety level of the patients.

Keywords: Anxiety, cancellation of surgery, State-Trait Anxiety Scale, surgery

\section{Giriş}

Cerrahi, organizmanın anatomik ve fizyolojik temel yapısını olabildiğince koruyarak, hastalık, travma ve deformitelerle bozulan beden fonksiyonlarının eski anatomik ve fizyolojik yapısına en uygun duruma getirilmesine yönelik yapılan bir tedavi yöntemidir. Cerrahi girişim ameliyat öncesi, ameliyat sırası ve ameliyat sonrası dönemlerden oluşmaktadır. Ameliyat olacak hasta için, cerrahi girişim tüm dönemleri ile birlikte stres yaratan bir durumdur. Buna karşın ameliyat yaşam dengesini tehdit eden birçok olumsuz özelliğin yanı sıra olumlu yönleri de olan bir yaşam deneyimidir. Hastalar bu iki yönlü deneyimin daha çok olumsuz yönlerini yaşamaktadır. Ameliyat ve ameliyat sonrası dönem hasta için bilinmeyenlerle dolu bir süreçtir. Bu süreçte birey doğrudan kendisini fiziksel tehdit altında hissetmeye başlar ve bir yaşam krizi yaşanmasına neden olur. Bu yaşantının verdiği gerginliğe birey fizyolojik ve davranıșsal birtakım tepkilerde bulunur. Yaşam bulgularında değişim ve anksiyete hali bu tepkilerin en belirgin olanlarıdır [1-3].

Ameliyat öncesinde hastanın anksiyete düzeyini, yapılacak işlemler hakkında bilgi sahibi olmaması, hastanın kişisel özellikleri, yaşı, anestezi ve cerrahi öyküsü, yapılacak operasyon tipi gibi birçok faktör etkilemektedir. Ameliyat öncesi dönemde hastaların anksiyetesinin yüksek olduğu yapılan çalışmalarda bildirilmiştir [4-6]. Aynı çalışmalarda ameliyat öncesi dönemde anksiyetesi daha az olan hastalarda ameliyat sonrası dönemde iyileşme süreci hızlandığına, hastanede kalış süresi kısaldığına ve normal günlük yaşam aktivitelerine daha k1sa sürede döndüğüne dikkat çekilmiştir. Ancak cerrahi kliniklerde planlı olan cerrahi girişimlerin son anda farklı sebeplerden dolayı ertelenmesi sık karşılaşılan durumlardandır [7,8]. Günümüzdeki teknolojik gelişmeler ve birçok hastanede hayata geçirilen kalite iyileştirmelerine rağmen cerrahi girişimler ertelenebilmektedir. Ameliyatın ertelenmesi durumunun hastanın anksiyetesini nasıl etkilediği tam olarak bilinmemektedir. Literatür incelendiğinde yapılan çalışmalarda daha çok ertelenme nedenleri, bu ertelenmelerin cerrahi bölümlere göre dağılımları, hasta sonuçlarına etkisi ve bunun ekonomik sonuçları üzerine odaklanıldığı görülmektedir [9-24]. Ulusal literatürde ise ertelenen cerrahi girişim nedenleri ve hasta anksiyetesi üzerine yapılan çalışmalar oldukça sınırlıdır. Ülkemizde cerrahi girişimlerin ertelenme nedenlerinin belirlenmesi ve bu nedenlere yönelik çözümler geliştirilmesine gereksinim olduğu açıtır. Ayrıca insanların içinde yaşadığ1 toplumun yapısına göre hastalıklara karşı verdiği tepkinin şekillendiği düşünüldüğünde cerrahi girişim kararı ertelenen hastaların anksiye düzeyinin değerlendirilmesinin önemi görülmektedir. Bu durum tespiti sağlık bakım hizmetlerinin şekillenmesine rehber olabilir. $\mathrm{Bu}$ araştırmanın amacı cerrahi girişimlerin ertelenme nedenlerinin incelenmesi ve ertelenmenin hasta anksiyetesi üzerine olan etkisini belirlemektir.

\section{Materyal ve Metot}

2.1.Araştırmanın Tipi: $\mathrm{Bu}$ araştırma tanımlayıcı tipte bir çalışmadır.

2.2.Araştırmanın Yapıldı $\breve{l}$ Yer ve Tarih: Bu araştırma Batı Karadeniz Bölgesinde yer alan bir Sağlık Uygulama ve Araştırma Merkezi'nin genel cerrahi servisi, ortopedi ve travmatoloji servisinde yürütüldü. Sağlik Uygulama ve Araştırma Merkezi, Sağlık Bakanlığı tarafından "sağlıkta kalite standartları" çerçevesinde hizmet sunmaktadır. Araştırma verileri Ocak 2017- Ocak 2018 tarihleri arasinda topland1.

2.3.Evren ve Örneklem: $\mathrm{Bu}$ araştırmanın evrenini çalışmanın yapıldığı tarihler arasında genel cerrahi servisi, ortopedi ve travmatoloji servisine yatış yapılarak cerrahi tedavi alan ve cerrahi girişimi ertelenen hastalar oluşturdu. Araştırmada herhangi bir örnekleme yöntemine gidilmeksizin ulaşılabilen ve çalışmaya katılmaya gönüllü olan hastalar yer aldı. Örneklem büyüklüğü ilgili literatürden $[9,10], \% 5$ kabul edilebilir hata ile ve $\% 95$ güven aralığında 82 olarak hesaplandı. Örneklemi toplam 100 hasta oluşturdu. Hastalar cerrahi girişimi ertelenen $(n=50)$ ve cerrahi girişimi ertelenmeyen $(n=50)$ olmak üzere iki gruba ayrıldı.

2.4.Veri Toplama Araçları: Araştırmada veri toplama araçları olarak hasta bilgi formu, Durumluk Anksiyete (STAI-I) ve Sürekli Anksiyete Ölçeği (STAI-II) Ölçeği kullanıldi.

Hasta Bilgi Formu: İlgili literatür [10-23] doğrultusunda oluşturulan Hasta Bilgi Formunda yaş, cinsiyet, eğitim düzeyi gibi demografik özellikler ve planlanan cerrahi girişim, planlanan cerrahi girişim ertelendiyse nedeni, cerrahi girişimin ertelendiğini açıklayan kişinin kim olduğu, yapılan açıklamanın yeterli bulunup bulunmadığına dair sorular yer aldı.

Durumluk Anksiyete (STAI-I) ve Sürekli Anksiyete Ölçeği (STAI-II) Ölçeği:

Durumluk Anksiyete Ölçeği (STA-I), bireyin belirli bir anda ve belirli koşullarda kendini nasıl hissettiğini, Sürekli Anksiyete Ölçeği (STAI-II) ise bireyin içinde bulunduğu durum ve koşullardan bağımsız olarak kendini nasıl hissettiğini belirler. Durumluk Anksiyete (STAI-I), Sürekli Anksiyete Ölçeği (STAI-II); 1970 
yılında Spielberger tarafından geliştirilmiş, Türkçe formu Öner N ve Le Compte A tarafından (1983) uyarlanarak geçerlilik-güvenirlik çalışması yapılmıştır. Türkçe formun iç tutarlığı ve güvenirliği Kuder Richardson alfa güvenirliğinde Durumluk Anksiyete Ölçeği için 0,94 ile 0,96; Sürekli Anksiyete Ölçeği için 0,83 ile 0,87 arasında bulunmuştur. Ölçeklerin her biri 20 maddeden oluşmaktadır. Yanıtlar 1-4 arasında puanlanmaktadır. Her bir ölçekten elde edilen toplam puan değeri 20-80 arasındadır. Yüksek puan kayg1 düzeyinin yüksek olduğunu gösterir $[25,26]$.

2.5.Verilerin Toplanması: Veriler cerrahi girişimi ertelenen hastalarda bu bilginin verildiği gün içerisinde, ameliyat sürecinde aksaklık yaşamayan hastalarda ise ameliyat sonrası aynı gün içerisinde araştırmacılar tarafından yüz yüze görüşme yöntemi ile toplandı.
2.6.Verilerin Analizi: Verilerin analizinde SPSS

(Statistical Package for the Social Sciences)19.0 istatistik paket programı kullanıldı. Araştırmada yüzde, frekans, ortalama gibi tanımlayıcı istatistiksel yöntemler ile Student $t$ testi, Pearson Kikare testi ve Fisher-FreemanHalton Exact Testi kullanıldı. Anlamlılı $\mathrm{p}<0,05$ düzeyinde değerlendirildi.

2.7.Araştırmanın Etik Yönü: Bir üniversitenin Girişimsel Olmayan Klinik Araştırmalar Etik Kurulu'ndan (26.10.2016 / 3) etik onay ve çalışmanın yürütülebilmesi için kurumdan yazılı izin alındı. Hastalara araştırmanın amacı açıklanarak sözlü izinleri ile çalışmaya katılımları sağlandi.

\section{Bulgular}

Araştırma kapsamına alınan hastaların bireysel özellikleri Tablo 1'de gösterildi.

Tablo 1. Gruplara Göre Hastaların Bireysel Özelliklerinin Karşılaştırması

\begin{tabular}{|c|c|c|c|c|c|}
\hline & & Cerrahi gi & & $\chi^{2}$ & $p$ \\
\hline & & Ertelenen & Planlı & & \\
\hline & & n $(\%)$ & n $(\%)$ & & \\
\hline Cinsiyet & Kadın & $25(46,3)$ & $29(53.7)$ & 0,644 & 0,422 \\
\hline & Erkek & $25(54.3)$ & $21(45.7)$ & & \\
\hline Yaş (yıl) & 20-40 yaş & $9(40.9)$ & $13(59.1)$ & & \\
\hline & 41-60 yaş & $22(42.3)$ & $30(57.7)$ & 7.497 & $0,024^{*}$ \\
\hline & 61-80 yaş & $19(73.1)$ & $7(26.9)$ & & \\
\hline Eğitim düzeyi & İlk ve orta öğretim & $36(54.5)$ & $30(45.5)$ & 1,604 & 0,205 \\
\hline & Lise ve Üniversite & $14(41.2)$ & $20(58.8)$ & & \\
\hline Medeni durum & Evli & $43(55.1)$ & $35(44.9)$ & 3,730 & 0,053 \\
\hline & Bekar & $7(31.8)$ & $15(68.2)$ & & \\
\hline Meslek & Ev hanımı & $19(47.5)$ & $21(52.5)$ & & \\
\hline & Çalışan & $18(45.2)$ & $23(54.8)$ & 2.481 & 0,289 \\
\hline & Emekli & $12(66.7)$ & $6(33.3)$ & & \\
\hline
\end{tabular}

Pearson Ki-kare Test

Cerrahi girişimi ertelenen hastaların bireysel özellikleri değerlendirildiğinde $\% 54,3$ 'ünün erkek, \%73,1'inin 6180 yaş grubunda, $\% 54,5^{\prime}$ inin ilk ve orta öğretim düzeyinde, $\% 55,1$ 'inin evli, $\% 66,7$ 'sinin emekli olduğu belirlendi. Hastaların cinsiyetlerine göre cerrahi girişimlerinin ertelenme oranları istatistiksel olarak anlamlı farklılık göstermezken ( $>0.05$ ); yaş gruplarına göre cerrahi girișimleri ertelenme oranlarının anlamlı farklılık gösterdiği, 61-80 yaș aralığında olanlarda

Tablo 2. Planlanan/Uygulanan Cerrahi Girişim Türlerinin Karşılaştırması

\begin{tabular}{|c|c|c|c|c|}
\hline \multirow{3}{*}{ Cerrahi girişimler } & \multicolumn{2}{|c|}{ Cerrahi girişim } & \multirow{3}{*}{$\chi^{2}$} & \multirow[t]{3}{*}{$p$} \\
\hline & Ertelenen $(\mathrm{n}=50)$ & Planlı $(n=50)$ & & \\
\hline & n $(\%)$ & n $(\%)$ & & \\
\hline \multirow{6}{*}{$\begin{array}{l}\text { Alt batın cerrahisi } \\
\text { Üst batın cerrahisi } \\
\text { Endokrin cerrahisi } \\
\text { Kırık onarımı } \\
\text { Diz ya da kalça protezi } \\
\text { Amputasyon }\end{array}$} & \multirow{6}{*}{$\begin{array}{l}28(56,0) \\
7(14,0) \\
4(8,0) \\
5(10,0) \\
4(8,0) \\
2(4,0)\end{array}$} & $23(46,0)$ & & \\
\hline & & $9(18,0)$ & & \\
\hline & & $3(6,0)$ & 3,749 & 0,619 \\
\hline & & $11(22,0)$ & & \\
\hline & & $3(6,0)$ & & \\
\hline & & $1(2,0)$ & & \\
\hline
\end{tabular}

Fisher-Freeman-Halton Exact Test, $\mathrm{x}^{2}$ : ki-kare testi 
Cerrahi girişimi ertelenen hastaların \%56'sına alt batın cerrahisi, \%14'üne üst batın cerrahisi, \%8'ine endokrin cerrahisi, \%10'una kırık onarımı, \%8'ine diz ya da kalça protezi, \%4'üne de amputasyon ameliyatı planlandığ belirlendi. Planlanan/uygulanan cerrahi girişim yönünden gruplar arasında istatistiksel olarak anlamlı farklılığın olmadığı saptandı ( $\mathrm{p}>0.05$; Tablo 2).

Araştırma örneklemini oluşturan cerrahi girişimi ertelenen hastalarda cerrahi girişimin ertelenme nedenleri, ertelenme kararının kimin tarafından açıklandığı ve bu açıklamanın yeterlilik düzeyi Tablo 3'de gösterildi.

Tablo 3. Cerrahi Girişimin Ertelenme Nedenleri, Açıklamayı Yapan Kişi, Açıklamanın Yeterliliği $(\mathrm{n}=50)$

\begin{tabular}{|c|c|c|c|}
\hline & & $\mathbf{n}$ & $\%$ \\
\hline \multirow[t]{7}{*}{ Ameliyatın erteleme nedeni } & Enfeksiyon/ateş & 9 & 18,0 \\
\hline & Akciğer fonksiyonlarında ani değişiklikler & 9 & 18,0 \\
\hline & Anormal test sonuçları & 7 & 14,0 \\
\hline & Ayılma odası ve yoğun bakım eksikliği & 7 & 14,0 \\
\hline & Ameliyathaneden kaynaklanan sorunlar & 7 & 14,0 \\
\hline & Hekimin plan değişikliği & 6 & 12,0 \\
\hline & Anesteziden kaynaklanan sorunlar & 5 & 10,0 \\
\hline \multirow{3}{*}{$\begin{array}{l}\text { Ameliyatın } \quad \text { ertelendiğini } \\
\text { açıklayan kişi }\end{array}$} & Asistan & 25 & 50,0 \\
\hline & Hemşire & 20 & 40,0 \\
\hline & Cerrah & 5 & 10,0 \\
\hline \multirow[t]{3}{*}{ Açıklamanın yeterlilik düzeyi } & Evet/yeterli & 30 & 60,0 \\
\hline & Kismen yeterli & 15 & 30,0 \\
\hline & Hayır/ yetersiz & 5 & 10,0 \\
\hline
\end{tabular}

Cerrahi girişimi ertelenen hastalarda cerrahi girişimin ertelenme nedenleri incelendiğinde; \%18'lik eşit oranlarda enfeksiyon/ ateş ve akciğer fonksiyonlarında ani değişiklikler, \%14'lük eşit oranlarda anormal test sonuçları, ayılma odası ve yoğun bakım eksikliği, ameliyathaneden kaynaklanan sorunlar, \%12'sinin hekimin plan değişikliği ve \%10'unun anesteziden kaynaklanan sorunlar olduğu saptandi. Ameliyatın ertelendiğini açıklayan kişinin \%50 oranında asistan, $\% 40$ oranında hemşire ve $\% 10$ oranında cerrah olduğu belirlendi. Hastaların \%60'ının ameliyatın ertelenme açıklamasını yeterli düzeyde, \%30'unun ise k1smen yeterli düzeyde bildirdikleri saptandı (Tablo 3 ).

Cerrahi girişimin ertelenme durumuna göre hastaların durumluk-sürekli kaygı durumu Tablo 4'de gösterildi.

Tablo 4. Cerrahi Girişimin Ertelenme Durumuna Göre Durumluk-Sürekli Kaygı Ölçek Puanlarının Karşılaştırması

\begin{tabular}{|c|c|c|c|c|c|}
\hline & \multicolumn{2}{|c|}{ Cerrahi girişim } & \multirow[t]{2}{*}{$\mathbf{t}$} & \multirow[t]{2}{*}{$p$} \\
\hline & & $\begin{array}{l}\text { Ertelenen } \\
(\mathbf{n}=\mathbf{5 0})\end{array}$ & Planlı $\quad(n=50)$ & & \\
\hline \multirow[t]{2}{*}{ Durumluk kaygı } & Min-Mak (Medyan) & $20-61(45)$ & $22-65(43,5)$ & 0,073 & 0,942 \\
\hline & $O r t \pm S s$ & $43,04 \pm 9,50$ & $42,90 \pm 9,61$ & & \\
\hline \multirow[t]{2}{*}{ Sürekli kaygı } & Min-Mak (Medyan) & $35-57(45)$ & $24-58(43)$ & 2,099 & $0,038^{*}$ \\
\hline & $O r t \pm S s$ & $45,28 \pm 5,67$ & $42,56 \pm 7,20$ & & \\
\hline
\end{tabular}

Student $t$ Test, ${ }^{*} \mathrm{p}<0.05$, Min: minimum, Mak: maksimum, Ort: Ortalama, Ss: Standart sapma.

Cerrahi girişimi ertelenen hastaların durumluk kaygı puan ortalaması $43.04 \pm 9.50$ ve cerrahi girişimleri planlı şekilde gerçekleştirilen hastaların puan ortalaması 42.90 \pm 9.61 'dir. Cerrahi girişimlerinin ertelenme durumuna göre hastaların durumluluk kaygı puanları arasında istatistiksel olarak anlamlı farklılık olmadığ saptand $1(\mathrm{p}>0.05)$.

Cerrahi girişimi ertelenen hastaların sürekli kaygı puan ortalaması $45.28 \pm 5.67$ ve cerrahi girișimleri ertelenmeyen hastaların puan ortalamas1 $42.56 \pm 7.20$ 'dir. Cerrahi girişimleri ertelenen hastaların sürekli kaygı puan ortalamalarının cerrahi girişimi planlandığ 1 gibi gerçekleştirilen hastalardan istatistiksel olarak anlamlı şekilde daha yüksek olduğu tespit edildi ( $\mathrm{p}=0.038$; Tablo 4).

\section{Tartışma}

Ameliyat süreci her hasta için önemli bir anksiyete nedenidir. $\mathrm{Bu}$ süreçte ameliyatın ertelenmesi gibi istenmedik bir durumun yaşanması ise kaygının daha fazla artmasına ve hasta bakım kalite sonuçlarının kötüleşmesine neden olur. Cerrahi girişimlerin ertelenmesi birçok hastanede sıklıkla karşılaşılan bir durumdur. Ertelenen cerrahi girişimlerin nedenleri arasında hastaların tıbbi durumlarındaki yetersizliklerin ön planda olduğu görülmektedir $[1,7,8]$. Sudan'da (2016) yapılan bir çalışma sonucunda iptal oranının 
\%20,2 olduğu [24], Ürdün'de (2015) yapılan bir çalışma sonucuna göre ise bir y1l içerisinde uygun şartlarda planlanan 7163 ameliyatın \%7,72'sinin iptal edildiği ve iptal edilme nedenlerinin ise en fazla hasta ile ilgili durumlar en az ise ekipman ve cihazlarla ilgili olduğu bildirilmiştir [17]. Kore'de (2018) yapılan bir çalışma sonucuna göre 10 yıllı tıbi kayıtlar değerlendirildiğinde; 60.333 ameliyatta iptal oranın $\% 8$ olduğu ve hastaların yaş seviyesi yükseldikçe iptal edilme oranın arttığı ve hasta kaynaklı iptal oranının $\% 93,2$, hastane kaynaklı iptal oranının ise $\% 6,8$ olduğu rapor edilmiştir [11]. İspanya'da (2009) yapılan bir çalışma sonucuna göre cerrahi girişimlerin $\% 50$ ' sinin tıbbi nedenlerden dolayı iptal olduğu ve bu tıbbi nedenler arasında \%18' inin enfeksiyon bunların büyük çoğunluğunda ise solunum yolu enfeksiyonu olduğu bildirilmiştir [12]. $\mathrm{Bu}$ güncel araştırma sonucunda da literatürle benzer olarak hastaların enfeksiyon, ateş, akciğer fonksiyonlarındaki ani değişiklikler ve yaşlı olan hastalarda anlamlı olarak cerrahi girişimlerin iptal edildiği belirlenmiş̧tir. Bu sonuçlara göre ameliyat öncesi yeterli olarak tıbbi iyilik halinin sağlanamaması cerrahi girişimlerin iptali için önemli bir neden olarak güncelliğini koruduğu görülmektedir [1].

İleri yaş ve bununla bağlantılı olarak hastanın tıbbi durumundaki yetersizlikler cerrahi girişim sonrası yoğun bakımda ya da kliniklerde daha uzun süreli tedavi ve bakımı gerektirmektedir. $\mathrm{Bu}$ doğrultuda yoğun bakımlarda ya da kliniklerdeki yatak kapasitesinin yetersizliği de cerrahi girișimlerin iptali için önemli diğer bir nedendir [13]. Literatürde, cerrahi girișimlerin $\% 24,7$ 'sinin idari / hizmet aksaklı̆̆ nedeniyle ertelendiği [14], ameliyat sonrası derlenme odasındaki yatak yetersizliği nedeniyle iptal edilen ameliyat oranının \% 15 \%18.9 arasında olduğu [13-15], yoğun bakımdaki yatak sayısının ve ventilatörlerin yetersizliği nedeniyle ertelenen cerrahi girişimlerin oranını $\% 5.58$ olduğu [16] bildirilmiştir. Bununla birlikte acil operasyonların mevcut yatak sayısını azalttı $\breve{g}$, uygun şartlarda planlanan cerrahi girişimlere göre tedavi oranını azalttığı ve böylece cerrahi hizmetin verimliliğini azalttığı gösterilmiștir [15]. Bu güncel çalıșma sonucunda da literatür ile benzer olarak cerrahi girişimlerin \%14'ünün derlenme odası ve yoğun bakımlardaki yatak sayısındaki yetersizlik nedeniyle ertelendiği belirlenmiştir.

Ameliyat için gerekli olan cerrahi aletlerin hazırlığı, bazı özel cerrahi aletlerin temininde yaşanan sorunlar, sınırlı sayıdaki cerrahi setler, ameliyathane personelinin sayısal yetersizliği, sterilizasyon ile ilgili gecikmeler, cerrah ile ekip arasındaki iletişim eksikliği gibi ameliyathane kaynaklı nedenlerden dolayı cerrahi girişim ertelenebilmektedir [18,27]. Bu güncel çalışmada, ertelenen cerrahi girișimlerin $\% 14,0$ ' ünün nedeninin ameliyathane kaynaklı sorunlar olduğu belirlenmiștir. Hsiao ve ark. (2004) ekipmanların taşınmasında zaman kazanmak ve böylece ameliyathanede zamanı iyi kontrol etmek için minimal invaziv cerrahi aletlere sahip olmayı önermişlerdir [27]. Bu sorunun çözümüne yönelik farklı bir öneri ise haftalık, günlük planlanan ameliyathane listesi için gerekli olan aletlerin, ilaçların ve diğer ekipmanların gerekliliği, bir gün önce cerrah, hemşire ve anestezi uzmanı arasında görüşülerek fikir birliği oluşturularak yapılması yönündedir [18].

Acil cerrahi girişimlere öncelik verilmesi, yapılan ameliyat programındaki değişiklikler, cerrahi ekipten birinin rahatsızlanması ya da cerrahın özel sorunları nedeniyle yapilan ertelemeler hekimin plan değişikliğiyle yaptığı ertelenmeler içinde yer almaktadır $[7,8,10]$. Literatürde farklı çalışma sonuçlarına göre hekim kaynaklı cerrahi girişimlerin ertelenme oranlarının $\% 5,4$ ile $\% 41$ arasında olduğu bildirilmektedir $[1,19,20,28]$. Cerrahi girişimlerin ertelenmesinde yeterli sayıda cerrahın bulunmaması, acil durumlar nedeniyle cerrahların farklı bir yerde bulunmak zorunda olması, ameliyat için cerrahın gecikmesi, yorgun olması, tedavi yöntemini değiştirmesi ya da yanlış tanı konulması gibi nedenler de yer almaktadır [21,22]. Afzal ve ark. (2010) yaptıkları çalışmada genç doktorların cerrahi planın tam olarak farkında olmadıklarını ve alışılmadık yöntemlerle hazırlanan uzun ameliyat listelerinin ameliyatların iptaline neden olduğunu bildirmişlerdir [16]. Pandit ve ark. (2006) ise uzun olan ameliyathane listelerinin, ameliyat günü vakaların iptal edilmesinin en yaygın nedeni olduğu sonucuna varmışlardır [21]. Bu güncel çalışmada ertelenen cerrahi girişimlerin \% $\% 12,0^{\prime}$ sinin hekimin plan değişikliği nedeniyle gerçekleştiği belirlenmiștir.

Cerrahi ekipte vazgeçilmez olan anestezi uzmanları sıklıkla ameliyathanelerde yönetici olarak da görev alırlar [10,18]. Yapılan çalışmalarda anestezi ekibinden kaynaklı olarak cerrahi girişimlerin iptal oranlarının $\% 8$ ile $\% 43$ arasında olduğu bildirilmiştir [15,22,23]. Bu güncel çalışma sonucunda da iptal edilen cerrahi girişimlerin \%10,0'unun anesteziden kaynaklanan sorunlar nedeniyle olduğu saptanmıştır. Ameliyat öncesi hasta değerlendirmesindeki yetersizlikler ya da ameliyat öncesi hastayı değerlendiren anestezi uzmanı ile ameliyata atanan anestezi uzmanı arasındaki görüş farklıll $\breve{g}_{1}$ gibi sebeplerden dolayı cerrahi girişim ertelenebilmektedir. Ameliyat öncesi değerlendirmeyi yapan anestezi uzmanının ameliyat sırasında da hasta bakımını sürdürmesi olası ameliyat iptallerini azaltacaktır [29].

Cerrahi girişimin ertelenmesi kararının hastaya bildirilme şekli ve kimin tarafından bildireceği hastanın anksiyetesini etkileyebilecek faktörlerdir. Dadaş Eldaş ve Eti Aslan'ın (2004) yaptığı çalışmada hastalara erteleme kararının $\% 52$ oranında hemşire ve hekimin birlikte verdiği ve $\% 54$ 'ünün yapılan açıklamayı yeterli bulduğu ifade edilmiştir [10]. Bu güncel çalışma bir üniversitenin sağlık eğitim ve araștırma merkezinde yürütülmüştür. Bu kurumlarda eğitim önceliklidir. Bu anlamda asistanlar hasta değerlendirmesini yapan sağlık çalışanlarıdır. Bu güncel çalışmada cerrahi girişimin ertelenme bilgisini $\% 50$ asistanlar ve $\% 40$ oranında da hemşireler tarafindan verildiği belirlenmiştir. Hastaların büyük çoğunluğunun yapılan açıklamayı yeterli bulduğu görülmüştür.

Cerrahi girişim öncesinde bekleme ve bu bekleme süresinin uzaması hasta için önemli bir kaygı nedenidir. 
Spielberger'in durumluk- sürekli kayg1 teorisine göre; geçici veya durumluk kaygı düzeyi, tehlike gibi tehdit edici bir durum algılandığında yükselir ve göreceli olarak az tehlikeli ya da tehlikesiz durumlarda düşer. Sürekli Kayg1 ise ortada nesnel bir neden yokken de var olan ve böyle bir neden olduğunda da bu durumla orantısız biçimde uzun süreli ve şiddetli olan kaygıdır. Bununla birlikte; sürekli kaygı düzeyi durumsal streslerden etkilenmez [26]. Bu teoriye göre, durumluk kayg1 anlık olaylarla ilgili olduğundan, çalışmamızda ameliyatı ertelenen grupla ertelenmeyen grup arasında istatistiksel olarak anlamlı bir fark saptanmamıştır; fakat süreklilik kaygı düzeyinin ameliyatı ertelenen grupta ertelenmeyen gruba göre daha yüksek olduğu görülmüştür. Kaygı'nın, kişilik, durum ve olay kaynaklı olmak üzere üç farklı türü bulunmaktadır. Bazı bireylerde sürekli bir durum olarak karşılaşılan kişilik kaynaklı kaygı, insan kişiliğinin bir parçasıdır [3]. Bu güncel çalışmada cerrahi girişimi ertelenen hastalarda sürekli kaygı puanlarının yüksek olmasının kişisel özelliklerin bir yansıması olabileceğin düşündürmüştür. Dadaş Eldaş ve Eti Aslan'ın (2004) yaptıkları çalışmada cerrahi girişimin ertelendiği hasta grubunda, erteleme kararı açıklandıktan sonra durumluluk anksiyete puanlarının cerrahi öncesine göre anlamlı olarak yükseldiği belirtilmiştir [10]. Kırçiçek Deliktaş ve ark. (2017) yaptığı çalışmada da premedikasyon odasında bekleme süresinin uzunluğunun, hastaların kaygı seviyelerinde anlamlı bir değişim yaratmadığ 1 belirlenmiştir [6]. Plan değişikliği nedeniyle yapilan ertelemelerde, durumun hastaya ve ailesine sağlık personelinin ekip olarak yapacağı yeterl açıklama ile ertelemeye bağlı gelişebilecek olası olumsuzlukların ve anksiyetenin azalacağını düşünülebilir.

\section{Sonuç}

Sonuç olarak bu güncel araştırma planlanan cerrahi girişimin ertelenmesinin hastaların sürekli kaygı düzeyini artırdığını gösterdi. Cerrahi girișim, tedavi olmayı sağlayabilecek kadar olumlu bir olay olmasına rağmen; içerdiği bilinmezlikler nedeniyle çoğu hasta için belirli düzeyde anksiyete yaratan bir durumdur. Anksiyete cerrahiyi, anesteziyi ve ameliyat sonrası iyileşme sürecini olumsuz etkiler. Ameliyat öncesi hasta değerlendirmesi yapılırken özellikle hastaların anksiyete düzeyinin de belirlenmesinin önemli ve gerekli olduğu görülmektedir. Anksiyetesi yüksek olan hastalar için ek girişimler düşünülmelidir. Ayrıca cerrahi girişim öncesi yeterli hazırlık yapılmalı, ertelenmeye neden olabilecek olası tıbbi hastalıklar belirlenmeli, gerekli önlemler alındıktan sonra cerrahi girişim planlanmalıdır.

\section{Referanslar}

1. Garg, R, Bhalotra, AR, Reasons for cancellation of cases on the day of surgery-a prospective study, Indian Journal of Anaesthesia, 2009 $53(1), 35-39$.

2. Yıldız Fındık, Ü, Yıldızeli Topçu, S, Cerrahi girişime alınış şeklinin ameliyat öncesi anksiyete düzeyine etkisi, Sağllk Bilimleri Fakültesi Hemşirelik Dergisi, 2012, 22-33.

3. Karadağ Arlı, Ş, Ameliyat öncesi anksiyetenin APAIS ve STAI-I ölçekleri ile değerlendirilmesi, Hacettepe Üniversitesi Hemşirelik Fakültesi Dergisi, 2017, 4(3), 38-47.

4. Arslan, S, Taylan, S ve ark., Nöroșirürji hastalarının ameliyat öncesi anksiyete düzeyleri, Anadolu Hemşirelik ve Sağlık Bilimleri Dergisi, 2017, 20(1), 17-21.

5. Cevik Acar, E, Yıldız Fındık, Ü, Ameliyathanede hastaların hemşirelik bakım kalitesi hakkında düşüncelerinin ve kaygı düzeylerinin değerlendirilmesi, Anadolu Hemşirelik ve Sağllk Bilimleri Dergisi, 2015,18(4), 268-273.

6. Kırçiçek Deliktaş, H, Açıkgöz, T ve ark, Elektif operasyon planlanan hastaların premedikasyon odasında bekleme sürelerinin anksiyete seviyelerine etkisi, Şişli Etfal Hastanesi Tip Bülteni, 2017, 51(4), 383-292.

7. $\mathrm{Yu}, \mathrm{K}, \mathrm{Xie}, \mathrm{X}$, et al, Contributing factors of elective surgical case cancellation: A retrospective cross-sectional study at a single-site hospital, Bio Med Central Surgery, 2017, 17(100), 2-8.

8. Mesmar, M, Shatnawi, NJ et al, Reasons for cancellation of elective operations at a major teaching referral hospital in Jordan, Eastern Mediterranean Health Journal, 2011, 17(8), 651-5.

9. Lankoande, M, Bonkoungou, $\mathrm{P}$ et al, Cancellation of elective surgical procedures in the university teaching hospital center Yalgado Ouedraogo in Burkina Faso: Incidence, reasons and proposals for improvement, SA Journal of Anaesthesia and Analgesia, 2016 22(5), 140-144.

10. Dadaş Eldaş, S, Eti Aslan, F. Ortopedik cerrahi girişimlerin ertelenme nedenleri ve ertelemenin hastaların anksiyete ve ağr düzeylerine etkisi, Acta Orthopaedica et Traumatologica Turcica, 2004, 38(3),212-219.

11. Cho, HS, Lee, YS et al, Reasons for surgery cancellation in a general hospital: A 10-year Study, International Journal of Environmental Research and Public Health, 2019, 16(7),2-16.

12. Gonza'lez-Are'valo, A, Gómez-Arnau, JI et al, Causes for cancellation of elective surgical proceduresin a Spanish general hospital, Anaesthesia, 2009, 64, 487-493.

13. Jonnalagadda, R, Walrond ER et al, Evaluation of the reasons for cancellations and delays of surgical procedures in a developing country, International Journal of Clinical Practice, 2005,59(6),71620 .

14. Schofield, WN, Rubin, G, Cancellation of operations on the day of intended surgery at a major Australian referral hospital, Medical Journal of Australia, 2005, 182, 612-5.

15. Zafar, A, Mufti, TS et al, Cancelled elective general surgical operations in Ayub teaching hospital, Journal of Ayub Medical College Abbottabad, 2007, 19 (3), 64-6.

16. Afzal, F, Asad, N et al, Causes of postponement of elective surgery in Mayo Hospital Lahore Department of Anaesthesia, Biomedica, 2010, 26, 148-151.

17. Al Khawalde, M, Al Gudah, F et al, Cancellation of elective surgical procedures, a single royalmedical services hospital experience, Journal of The Royal Medical Services, 2015, 22(4), 52-56.

18. Kumar, R, Gandhi, R, Reasons for cancellation of operation on the day of intended surgery in a multidisciplinary 500 bedded hospital, Journal of Anaesthesiology Clinical Pharmacology, 2012, 28(1),66-69.

19. Ezike, H, Ajuzieogu, VO et al, Reasons for elective surgery cancellation in a referral hospital, The Annals of Medical and Health Sciences Research, 2011, 1(2), 197- 202.

20. Desta, M, Manaye, A et al, Incidence and causes of cancellations of elective operation on the intended day of surgery at a tertiary referral academic medical center in Ethiopia, Patient Safety in Surgery, 2018, 12(25),2-6.

21. Pandit, JJ, Carey, A. Estimating the duration of common elective operations: implications for operating list management, Anesthesia, 2006, 61,768-776

22. Hussain, AM, Khan, FA. Anaesthetic reasons for cancellation of elective surgical inpatients on the day of surgery in a teaching hospital, Journal of Pakistan Medical Association, 2005, 55,374-8.

23. Karashi, AR, AlSaif, M, et al, Cancellation of elective procedures on the day of surgery, Bahrain Medical Bulltein, 2018, 40(1), 38-41

24. Mutwali, IM, Abbass, AM, et al, Cancellation of elective surgical operations in a teaching hospital at Khartoum Bahri, Sudan, Sudan Medical Monitor, 2016,11,45-51.

25. Spielberger, CD, Gorsuch, RL et al, Test manual for the State Trait Anxiety Inventory, 1 st ed. California: Consulting Psychologists Press, 1970.

26. Öner, N, Le Compte, A, Durumluk-Sürekli Kaygı Envanteri el kitabı, İstanbul: Boğaziçi Üniversitesi, 1983.1-26.

27. Hsiao, $\mathrm{KC}$, Machaidze et al, Time management in the operating 
room: an analysis of the dedicated minimally invasive surgery suite, Journal of Society of Laparoendoscopic Surgerons, 2004, 8,300-3.

28. Chamisa, I, Why is surgery cancelled? A retrospective evaluation, South African Journal of Surgery, 2008, 46(3),79-81.

29. Karnalkar, A, Karnalkar, P, Causes of cancellation for elective orthopedic procedures on the day of surgery, International Journal of Scientific Reports, 2015, 1(5), 235-238.

http://edergi.cbu.edu.tr/ojs/index.php/cbusbed isimli yazarın CBU-SBED başlıklı eseri bu Creative Commons Alınt1-Gayriticari4.0 Uluslararası Lisansı ile lisanslanmıştır.

cc) (7) (8) 